\title{
Smallholder Agricultural Finance in Nigeria: Literature Review on The Research Gap
}

\author{
Oluwamayokun Anjorin Fadeyi
}

\begin{abstract}
The aim of this paper is to first and foremost review various literatures on agricultural financing in Nigeria and study the various streams and impact of financing that are available to the smallholder farmers, and secondly, to propose a direction for future research in enhancing the utilization of these funds for sustainable development of smallholder farming in Nigeria.
\end{abstract}

This paper is based on review of articles identified using the following search algorithm: "agricultural", ("finance" or "funding" or "credit"), "Africa", and "Nigeria" published between 2015 to 2017. The author identified 146 articles from the Emerald Insight database and $\mathbf{7 2 2}$ articles from the ScienceDirect database After removing duplicates and carrying out a thorough analysis based on the problem studied, 59 papers were included in this study. The framework for evaluating the need for smallholder farming financing in Nigeria was studied based on the use of modern farming technology, the level of farm productivity and the livelihood of the farmers.

The definition of the term agricultural financing in this article was defined from the perspective of the provision of credit for agricultural activities by the smallholder farmers. While, several literatures that were reviewed indicated that there has been funding provisioned to the smallholder farming industry in Nigeria, but the impact of these funds in terms of level of farm productivity, use of modern farming technology and the livelihood of the farmers is yet to be experienced. To the best of my knowledge, limited study on the evaluation of institutional sector financing has so far been conducted.

Index Terms - Agricultural finance, Agricultural credit, Agricultural finance impact, Smallholder farmers, Smallholder farming.

\section{INTRODUCTION}

Globally, agriculture has been identified as a major component in the achievement of the second millennium development goals - to eradicate extreme poverty and hunger (Kersten, Harms, Liket, and Maas2017; United Nations, 2015), and as such the world's government has placed so much focus on the development of agriculture across the world. If the focus of world is to eradicate poverty using agriculture as a medium, new investments in agricultural research, and perhaps, technological developments directed towards enhanced agricultural farming systems are required (Jones \& Ejeta, 2016).

About three-quarter of the world's poor live in rural areas that are majorly involved in agricultural activities (Marris,

Oluwamayokun Anjorin Fadeyi, School of Agriculture and Food Sciences, University of Queensland, Australia. https://orcid.org/0000-0001-8645-6540
2018; World Bank, 2014). Furthermore, the agricultural products from these rural areas account for majority of the agricultural products in terms of crops and animal produce consumed in the cities across the world. To be able to continue with the production of agricultural products to match up with the world's increasing population, which is put at an annual growth rate of $1.7 \%$ (World Bank, 2016), it is inherent that these smallholder farmers move from the traditional method of farming to a more developed and improved technological way of farming (Ellinger \& Penson, 2014). Across the world, smallholder farming has been rediscovered as important in the eradication of poverty, creation of employment and provision of food for sustenance of the population (Röttger, 2015), and as such, nations are now focusing on the sector. A shift from the rural agricultural farming method to the modern agricultural farming method requires the flow of a consistent level of f unding (Ellinger \& Penson, 2014; Miller \& Jones, 2010; Olomola, 2010). Hence, steady and consistent access to finance by the smallholder farmers is critical for the much-required growth needed in the agricultural sector, hence agricultural financing.

The financing of agricultural activities, otherwise referred to as agricultural financing has been identified as an essential and crucial aspect of agriculture, as it is an important precursor needed to determine the quantity and quality of inputs in terms of technology, materials, and labour that can be used on the farm (Ellinger \& Penson, 2014; Miller \& Jones, 2010). Various authors have given various definition from different perspectives to the definition of agricultural finance, however, for this research, agricultural finance will be highlighted as it refers to the financial services provided for agricultural production, processing, and marketing (IFC, 2011); ranging from the institutional/formal and non-institutional/informal financial sources, to short term, medium term, and long term loans, to leasing. Agricultural finance "is a process of obtaining control over the use of money, goods and services (for agricultural purposes) in the present in exchange for a promise to repay an agreed amount at a future date" (Ejiogu, 2018, p. 10). It is also having access to credit for use to improve the efficiency of farm production and as a means of adopting better technology (IFC, 2011). A combination of the two definitions of agricultural finance indicate that agricultural finance entails the availability of a source of finance, the accessibility to the fund, utilization of the fund for agricultural purpose, and a plan to repay the fund in the future.

In African economies, agriculture has been identified as the largest sector in the provision of employment, supply of food and generation of earnings from export (Dercon \& Gollin, 2014) which are all part of the MDGs. Africa 
countries are also characterised by high population, giving rise to the need to continually meet the feeding demands of the increasing population. The above precursors serve as indicators to the importance of agriculture in Africa (Diao \& McMillan, 2017). Contrary to developed countries, agriculture in developing countries, mostly in Africa, is still characterised by low productivity, which, without an urgent intervention targeted towards the growth of the sector, agriculture will not attain its full potential (IFC, 2011; Olajide, Akinlabi, \& Tijani, 2012). In many African countries, the government's spending on agriculture is below the target set by the Comprehensive African Agriculture Development Program (CAADP), Maputo declaration of July 2003, where it was agreed upon that each government will allocate $10 \%$ of its state yearly budget to agriculture (Ali, Poomthan, \& Warunsiri, 2016). The deficit in the supply of the funds needed by the smallholder farmer has therefore formed the basis on which this research paper is founded.

\section{RESEARCH METHODOLOGY AND PROCEDURE}

\section{A. Methodology}

This literature review examines journals and papers dealing with the study of agricultural financing, particularly, financing for smallholder farmers, mainly published between 2015 and 2017, however, several articles have been published before 2015 that have addressed some specific solutions to agricultural financing (Iwuchukwu \& Igbokwe, 2012). F or this study, emphasis was placed on the financing of smallholder farmers in Nigeria in the twenty- first century (Adesina, 2013). The several contributions focused on institutional agricultural financing to the smallholder farmers in Nigeria, and specifically the impact of these finance on the smallholder farming sector in terms of the adoption use of modern farming techniques, increase in farm productivity, and livelihood of the smallholder farmers. Furthermore, different papers that addressed the topic of "Agricultural Credit", "Impact of Credit on Agriculture", "Agricultural finance" and "Rural Finance", have been incorporated in this study, on the basis that, there is at least some contributions made with relevance to the impact of finance on smallholder farming activities. Specifically, contributions relating to the sourcing, distribution and use of farm credit were included (Evbuomwan, 2016).

\section{B. Article Selection}

The process involved in the selection of the articles reviewed can be categorized into two stages. Stage one, a search was conducted using two major library databases Emerald Insight and ScienceDirect; and multiple keywords and strings - "agricultural", ("finance" or "funding" or "credit"), "Africa", and "Nigeria"; were checked for in the titles, abstracts as well as in the main body of the paper. Using this method, major agricultural finance and agricultural research journals were examined - World Development, Journal of Development Economics, International Journal of Social Economics, Agricultural Finance review, and African Journal of Agricultural Research. Additionally, the search also included international conference journals and published books. Articles that specified agricultural finance as well as agricultural credit just in the introductory comments or as a by-inquire were disposed of - these included articles that placed emphasis on poverty alleviation and rural development. Papers were carefully studied. Finally, 59 papers published between 2015 to 2017 were chosen for in-depth examination. In the second stage, the entirety of the work in the first selected set of samples of 868 journals were compiled and studied to identify those that are relevant to the study which were omitted in the keywords search carried out in stage one (Harris M. Cooper, 2009). This led to the identification of 160 articles, which were put aside based solely on the title, methodology, or context. From these, 45 more articles were discarded because they were found to be reports or working papers and lack the in-depth analysis needed for this study. Ultimately, 115 papers were selected for this study.

In summary, 59 papers were selected, which were all published between 2015 to 2017, 35 were published in international journals, 1 is a working paper, while the remainder are book chapters, and books.

\section{Review Method}

Several review methods used in papers been studies were examined (Kersten et al., 2017; Mattia, Riccardo, Alessandro, \& Angela, 2016). For this literature review and in line with (Mattia et al., 2016), the papers were categorized using the two-pronged approach. The articles were examined and grouped based on the research methodology used in the research and based on their content. The general agricultural finance and agricultural credit literature were analysed first to identify topics been examined, and any relevant solutions included. Following this, articles relating to the solution were studied and the papers were categorized according to the concept and definition of agricultural finance, types, sources and advantages of agricultural finance, and the current positions of agricultural finance. These papers were studied, reviewed and summarized using established criteria to identify the patterns of relationship between the studied papers and the topic and as well as to reveal possible research gaps.

\section{SMALLHOLDER FINANCE: FINDINGS FROM THE LITERATURE}

This section contains a brief of the features and content of the reviewed 59 papers. It also discusses the introduction and viewpoints of the research method, while the other subsections address the topics highlighted in the preceding section.

\section{A. Research Method}

As categorized by Mattia et al. (2016), the analysis presented below categorizes the reviewed papers according to five research methods which include the analytical models, theoretical framework, case studies, interviews and surveys. 
Table 1: Research Methodology Summary

\begin{tabular}{|l|l|l|}
\hline & Methodology & Number \\
\hline i & Analytical models & 32 \\
\hline ii & Theoretical frameworks & 16 \\
\hline Iii & Case studies & 5 \\
\hline iv & Interviews & 0 \\
\hline v & Surveys & 6 \\
\hline
\end{tabular}

A high number of the reviewed articles were based on the use of analytical models, while the others involved the use of a combination of theoretical frameworks and conceptual studies. Analytical models have been used in generality by most of the authors to identify the scope of smallholder farming finance and its relevance. Afolabi (2010), Evbuomwan (2016), Taiwo and Olurinola (2016) all used the analytical modelling to demonstrate the effects and relationship of micro-finance/credit and agricultural finance/credit to smallholder farmers. Martin and Clapp (2015) and Orebiyi, Eze, Henri-Ukoha, Akubude, and Ibitoye (2011) on the other hand used analytical modelling to identify the need and demand for agricultural finance to smallholder farmers, while Akinola (2013) and Okoro and Nwali (2017) also used the analytical model to identify the problems of agricultural financing, while Coker and Audu (2015) and Fadeyi (2013) used the analytical method to demonstrate how agricultural finance can be utilized by smallholder farmers and also proffer valuable contributions as to how agricultural finance can be better administered and better utilized for enhanced development of smallholder farms.

The articles reviewed that used the theoretical framework with regards to microfinance and agricultural finance focused on defining the scope of this study. Though, many of the conceptual papers reviewed focused on the prevalence of the need for finance and credit for the smallholder farmers rather than the solutions to the smallholder financing structure. However, Omorogiuwa, Zivkovic, and Ademoh (2014) provided a detailed study of the stakeholders involved in the financing system of smallholder farmers in Nigeria who provides funds to the smallholder farmers and their perception towards the repayment of the provided funds. In addition, Tersoo (2014) provided insights on how adequate and accessible finance can affect smallholder farming activities. With regards to the methodologies of empirical research, the literatures that were reviewed presented features of the use of surveys and statistical analyses data as studied by previous works (Afolabi, 2010; Falola, Ayinde, \& Agboola, 2014). For instance, Coker and Audu (2015) carried out a survey in Minna, Nigeria, while Afolabi (2010) conducted a survey in Oyo, Nigeria with a purpose to identify the effect of agricultural micro-credit on smallholder farming and the attitude of the beneficiary smallholder farmers to repayment. Notably, Afolabi (2010) utilized the statistical method to review the credit repayment attitude of beneficiary farmers.

\section{CONCEPT OF AGRICULTURAL FINANCE}

This section discusses the various definitions of agricultural finance as given in the various reviewed papers, these are then summarized in Table II. The various definitions give a clarity of the current state of agricultural finance and the viewpoint of the various authors as they have approached this topic. To categorize the various given definitions of agricultural finance, two factors were considered - the role of the finance providers and smallholder farmers, and the perspective from the author's viewpoint.

Some of the articles reviewed classified agricultural finance based on the term for which the fund is provided to the farmers. Some authors regarded agricultural finance as a set short-term financial solution provided by the financial providers, while some consider it as a long-term financial solution provided to smallholder farmers. Overall, the involvement of the financial provider is considered as the provision of solution to agricultural activities of the smallholder farmers.

Table 2: Definitions of Agricultural Finance

\begin{tabular}{|c|c|c|}
\hline No. & Article & Definition \\
\hline 1. & $\begin{array}{l}\text { Coker and } \\
\text { Audu } \\
(2015)\end{array}$ & $\begin{array}{l}\text { Investments made by developing } \\
\text { countries in agriculture - but also in } \\
\text { rural infrastructure, health, and } \\
\text { education-are both pro-growth and } \\
\text { pro-poor. }\end{array}$ \\
\hline 2. & $\begin{array}{l}\text { Kersten et } \\
\text { al. (2017) }\end{array}$ & $\begin{array}{l}\text { The provision of various types of } \\
\text { financial products, including } \\
\text { (subsidized) loans, credit lines, fiscal } \\
\text { credit, guarantees, matching grants, } \\
\text { priority-lending regulation, and } \\
\text { overdraft facilities. In some cases, the } \\
\text { aim of SME finance was to promote } \\
\text { R\&D and innovation (e.g., product } \\
\text { development). }\end{array}$ \\
\hline 3. & $\begin{array}{l}\text { Mattia et al. } \\
(2016)\end{array}$ & $\begin{array}{l}\text { Agricultural credit is the provision of } \\
\text { credit which is crucial to the } \\
\text { development of the farming sector. }\end{array}$ \\
\hline 4. & $\begin{array}{l}\text { Ali et al. } \\
(2016)\end{array}$ & $\begin{array}{l}\text { Agricultural credit is the financial } \\
\text { credit that should be made available } \\
\text { to farmers so that they can purchase } \\
\text { new equipment and mechanize their } \\
\text { farms. }\end{array}$ \\
\hline 5. & $\begin{array}{l}\text { Lowder, } \\
\text { Carisma, } \\
\text { and Skoet } \\
(2012)\end{array}$ & $\begin{array}{l}\text { It involves giving up something } \\
\text { today to accumulate assets that } \\
\text { generates increased income or other } \\
\text { benefits in the future. }\end{array}$ \\
\hline
\end{tabular}

Furthermore, the term agricultural finance was furthermore classified on their repayment rate based on the provider of the finance. 
Table 3: Classifications of Interest Rates of Agricultural Finance

\begin{tabular}{|l|l|l|l|}
\hline No. & Provider & $\begin{array}{l}\text { Repayment } \\
\text { Interest Rate }\end{array}$ & $\begin{array}{l}\text { Repayment } \\
\text { Interest Level }\end{array}$ \\
\hline 1. & Banks & Yes & High \\
\hline 2. & Government & Yes & Low \\
\hline 3. & $\begin{array}{l}\text { Donor } \\
\text { Agencies/Countries }\end{array}$ & No & Not Applicable \\
\hline
\end{tabular}

A major characteristic of all the papers reviewed highlighted that agricultural finance involve the provision of finance, or otherwise referred to as credit, to smallholder farmers, either on a short term, medium term or long term basis (Central Bank of Nigeria, 2018; Valentina, Denis, \& Xuan, 2015) for use on the farm, while the second main characteristic of the reviewed articles identify that farmers have the obligation to repay the fund at a later date (Afolabi, 2010), except where the fund is identified as grant or aid which requires no repayment (Fløgstad \& Hagen, 2017).

\section{FINANCING AGRICULTURE IN NIGERIA}

Nigeria, located in the western part of Africa, shares from the several attributes of the factors that affects agriculture in Africa. Nigeria, is a country with an agrarian climatic condition through the year, which is favourable for agricultural activities. The country has great potential to contribute to the global production and export of agricultural products like groundnut, cocoa, cassava, yam and maize because of its vast arable land, and as such many international countries, organizations and the government are interested in investing in the growth of agriculture in Nigeria, hence, financial aids and supports are being channelled to the agricultural sector in Nigeria. Also, with the realization that over $60 \%$ of the Nigerian population are employed in agriculture and food activities (Chukwuma Sr, 2014), the Nigerian government has over the years continually provided funding to the agricultural sector, so also have the banks and donor agencies. However, this fund has been argued to be inadequate for the needed development required in the agricultural sector in Nigeria (Evbuomwan, 2016) as the smallholder farming system is still characterised with local farming technologies. With over 50 years of funding from international organizations averaging at about USD185million per year as at 2001 (Okotie, 2018) and USD15,870million as at 2015 (OECD, 2018), and with an average government funding of USD48,621million as at 2001 and USD41,245Million in 2015 (Mogues \& Dillon, 2018), while banks have also committed $1.4 \%$ of their credit portfolio in 2008 to agriculture, and this increased to $1.7 \%$ in 2010 (Ofoegbu, 2015), agriculture development in Nigeria among the smallholder farmers still remain in the crude state.

Agriculture is an important and integral aspect of the Nigerian economy and its contribution to the country's gross domestic product (GDP) cannot be undermined. In 2006, agriculture contributed $32 \%$ to the GDP of the Nigerian economy, $32.71 \%$ in $2007,32.85 \%$ in 2008 , and $37.05 \%$ in 2009 (National Bureau of Statistics, 2017; Trading Economics, 2018; World Bank, 2018), these figures represent a decline in its contribution of $67.5 \%$ in 1957 (National Bureau of Statistics, 2017). Agriculture has undoubtedly been the main pillar of the Nigerian economy long before the discovery of crude oil in the country. Aside from its contribution to the GDP of the country, agriculture has also contributed to the creation of employment. About $48 \%$ of the nation's workforce was engaged in agriculture in 2006, $49 \%$ in 2007, with a gradual decline in 2008 to $44 \%, 31 \%$ in 2010 , and eventually $27 \%$ in 2015 (National Bureau of Statistics, 2017; Trading Economics, 2018; World Bank, 2014). With the several importance of agriculture to the Nigeria's economy, and its dwindling state, its restoration can only be achieved by empowering the people and facilitating their access to the various factors of production, especially credit (Ellinger \& Penson, 2014; Yahaya \& Osemene, 2011), hence the need for financial interventions.

\section{A. The Sources of Agricultural Finance in Nigeria}

In Nigeria, there are basically two major sources of funding available to smallholder farmers for their agricultural activities. These funds can be obtained from either the noninstitutional/informal financial sector or the institutional/formal financial sector.

\section{1) The Non-Institutional/Informal Sources of \\ Agricultural Finance in Nigeria}

The non-institutional/informal financial sector is characterised by funds from lending activities from cooperative societies, otherwise called esusu, borrowings from families or from money lenders. The non-institutional/informal financial market is dominated by monopolistic money lenders who charged exploitative interest rates, they also make demands for collaterals from the farmers. Such collateral are often personal belongings.

The cooperative society or credit thrift society form of non-institutional/informal finance, otherwise called the esusu is a form a contribution among people of like minds. The contribution can be daily, weekly, or monthly. There are two ways of administering this form of finance. First, the money can be given to the members of the society on rotational basis at the end of every week or month, or secondly, the money can be pooled together and given to the member that makes a request for a need at a defined interest rate (Afolabi, 2010). The money lenders are a form of local bank, though not instituted. They provide finance to the rural dwellers in short notices, but this type of fund is characterised but high interest rate. The repayment interest in some cases can be as high as $10 \%$ to $15 \%$ per month (Afolabi, 2010). Except where necessary, to be able to drive a successful farming business, it is best that such non-institutional/informal forms of agricultural funding be avoided, as agricultural process itself requires some few months of gestation before the crops planted can be harvested or the animal being reared can be sold, during which period the farmer would have been paying interest on the loan. If proper care is not taken, the interest been repaid on the loan can erode the profit of the farmer, as well as the capital.

\section{2) The Institutional/Formal Sources of Agricultural Finance in Nigeria}

Nigeria has the capacity to unleash its potential agricultural productivity to provide for the high demands of both the local 
and international market. However, this potential cannot be fully achieved except with adequate financing structure in place. The provision of structured agricultural finances could be the solution, and these structured funds are often obtained majorly from three sources, which are the government, banks, and international agencies/countries.

\section{a) Government Funding}

The major involvement of a nation's government in the agricultural sector of the country is a needed precursor to the development of agriculture and the overall economic progress of the country (Bezemer \& Headey, 2008). In Nigeria, the government have over time come up with various tools, programmes and agencies through which they aim to provide funds to the smallholder farmers. However, the funding of the government to the agricultural sector since the early 1980s has been on a variable pattern and is inconsistent. In 2013 , only $1.70 \%$ of the whole budget was allocated to agricultural development, this declined in 2014 to $1.47 \%$, then $0.90 \%$ in 2015 (Budget Office, 2018; World Bank, 2018). In 2016, there was a positive change in the government allocation to agriculture as the percentage of the budget allocation to agriculture increased to $1.25 \%$ and $1.26 \%$ in 2017 , and $1.38 \%$ in 2018. However, this is still below the mandatory $10 \%$ budgetary allocation for agricultural as recommended in the 2015 Comprehensive Africa Agriculture Development Program (CAADP) (Budget Office, 2018; Ofoegbu, 2015).

\section{b) Banks' Funding}

Banks form the larger part of the Nigerian financial industry, rendering financial services to the teeming Nigeria populace (Iwuchukwu \& Igbokwe, 2012). These services include but not limited to receiving deposits from customers, contract and local purchase order financing, and borrowing funds to the deficit sector. The smallholder farmers form part of the deficit sector that the Banks provide financing activities for. The advantages of banks are derived from their adversities, competitiveness, flexibility, lending competence, and high speed of response to customers request (Coker \& Audu, 2015; Taiwo \& Olurinola, 2016), it is however, doubtful if this sort of diversity is still obtainable in the context of the Nigerian banking industry. Nigerian banks are competent in the generation of credit deposits. Despite their potential to be a huge source of providing finances for agricultural loans, their portfolio of loans to agriculture is less when compared to that of the loans provided to the other sectors of the economy. Bank's credit portfolio to agriculture was $1.4 \%$ in $2008,1.4 \%$ as well in 2009 , and this increased to $1.7 \%$ in 2010 (Ofoegbu, 2015). There was however a high bank credit to the agricultural sector in 2011 of $3.5 \%$, as the government attempts to place more emphasis on agriculture (Central Bank of Nigeria, 2017; Eluhaiwe, 2014; Okoro \& Nwali, 2017).

\section{c) International Donor Funding}

Since the early 1950s, international governments and donor agencies have disbursed large amounts of funds on agricultural credit programs to Nigeria. Between mid-1950s to the late-1980s, the World Bank, as an agency, has committed over US\$16 billion to these efforts while other donors have also spent substantial amounts (Pardey,
Chan-Kang, Dehmer, \& Beddow, 2016) globally towards the development of agriculture across the globe especially in developing countries.

Nigeria, like many developing countries receives grants, financial aids and interventions, and donation from numerous external organizations, and donor countries. These funds are targeted towards the improvement of agriculture in developing countries for sustenance of agricultural productivity (OECD, 2018). It is aimed to assist countries with high number of smallholder farmers met the needed food production in their respective countries. The funds from the external agencies, organizations and donor countries are pooled together by the government and later disbursed to the smallholder farmers through a structured process with no repayment interest rate. The integrity of the disbursement of these funds are often a bone of contention as the administrators of these funds often prioritize the request of beneficiaries that they have personal benefits from. It has also been alleged that many of the beneficiaries of this fund, knowing that they are not required to repay, often collect the funds and do not invest it in farming activities (Akinola, 2013; Eluhaiwe, 2014). For instance, since 1985, International Fund for Agricultural Development (IFAD) invested a total of USD317.6million in 10 projects in Nigeria (IFAD, 2018), between 2007 - 2009, Nigeria received agriculture related international aid of an average of USD212.7million, USD205.7million between 2010 - 2012, and a high of USD348.9million between 2013 - 2015 (National Bureau of Statistics, 2007; OECD, 2018). Of these funds, some came from the Food and Agricultural Organization, the World Bank, the International Centre for Agricultural Research in the Dry Areas, the International Water and Sanitation Centre and the Department for International Development (Okoro \& Nwali, 2017).

\section{B. Agricultural Finance Projects}

Overall, several attempts have been made by the various authors - whose papers were reviewed, to research on agricultural finance project, and these papers can be broadly classified into two categories based on the purpose of the paper. Some of the articles reviewed were descriptive and presents the case studies of smallholder farmers who have successfully benefitted from credit for use on their farms, while the other articles reviewed were exploratory, presenting a set of strategies which are related to the utilization of agricultural finance for farming purpose. The purpose of the descriptive articles was first to highlight cases of the successful implementation of agricultural finance and present a descriptive analysis of the cases studied as contribution to the paper, or as support to the concept been utilized. Examples of the case study of the use of descriptive method include articles by Okoro and Nwali (2017), Eluhaiwe (2014), and Adesugba and Mavrotas (2016).

Some other articles were based on the use of exploratory methods to present a set plan towards the adoption and utilization of agricultural finance. These exploratory articles include articles by Falola et al. (2014), Afolabi (2010); Orebiyi et al. (2011); Taiwo and Olurinola (2016) and Yahaya and Osemene (2011). These articles adopted the use of several methodologies, empirical models and contextual 
variables which affects the decisions for the acquisition and utilization of credit by beneficiary farmers.

\section{Expected Benefits}

From the viewpoint of financial providers, the benefits accruable to the smallholder farmers from having access to agricultural finance and use of agricultural finance for their farming activities cannot be over emphasized (Hartarska, Nadolnyak, \& Shen, 2015). These benefits are well known and identified in studies that assessed the benefits of finance to farmers (Bezemer \& Headey, 2008; OECD, 2016). These benefits include but n ot limited to access to improved farm inputs (Gbandi \& Amissah, 2014), access to advanced and expensive technology (Olajide et al., 2012), and access to knowledgeable experts (Tersoo, 2014). However, these mentioned benefits are not the only benefits accruable to smallholder farmers who have access to funding, credit and/or aids (Fløgstad \& Hagen, 2017), other benefits include the low repayment interest rates (United Nations, 2015), as well as the convenience of the duration when the fund is to be repaid (Afolabi, 2010). The benefits of agricultural finance are not limited to the performance of the farming activities only, but it also extends to, and have an effect on the personal $\mathrm{life}$ of the smallholder farmers (Evbuomwan, 2016), whose livelihood are impacted upon by the resultant changes of the agricultural credit on their farming activities. Eze et al. (2010), Daneji (2011) and Iwuchukwu and Igbokwe (2012) reviewed the benefits of government's funding of the smallholder farming sector and how it has affected the success of smallholder farming, while Birthal et al. (2017), Okoro and Nwali (2017), and Yahaya and Osemene (2011) focused their study on the benefits of banks' funds to smallholder farmers and how it has been of advantage to the beneficiary farmers over their counterpart. On the other hand, Ndikumana and Pickbourn (2017) and Eicher (2003) concentrated their studies on the impact of aids and grants from donor organizations and donor countries. In general, the other articles reviewed highlighted the benefits of adequate funding and access to credit for smallholder farmers but, Coker and Audu (2015) and Afolabi (2010) raised concern about the attitude of beneficiary farmers to the repayment of the credit/funds that they have benefited from.

Finally, a summary of the reviewed articles noted that for agricultural finance to be successful for smallholder farmers, there is need for an enhancement of the funds from the various sources through adequate collaboration between the providers of the funds and the beneficiary farmers (Fløgstad \& Hagen, 2017; Olajide et al., 2012).

\section{THE RESEARCH GAP AND FUTURE RESEARCH}

Historically, after the era of colonization and at the start of the independence of several African countries such as Sudan in 1956, Ghana in 1957, and 16 other countries in $1960-$ including Nigeria, Africa and Nigeria in particular was a modest exporter of agricultural commodities like cotton, oil palm, cocoa, and groundnut (Eicher, 2003). But with the discovery of crude oil in Nigeria, there was a shift in the attention of the government from agriculture to oil exploration, agriculture was neglected (Adesina, 2013) and its activities were stagnated.
However, with the increasing and the high demand for agricultural commodities to feed the population, Nigeria which was once an exporter of agricultural commodities became and importer of food commodities. This posed a challenge to the government, and successive government introduced several schemes, policies and programs to arrest the declining agricultural state of the country (Röttger, 2015). However, after several years on investing in agriculture by the government, international agencies and banks, the impact of these investment on the development in the agricultural sector seemingly does not justify the investments that have been made, whereas this situation might be made worse in the near future as the population of Nigeria has been projected to be about 410million in 2050 (World Bank, 2018). This therefore brings to fore the call for the evaluation of the impact of the institutional finance on smallholder farming in Nigeria.

As at present, the shape, dimension and scope of agricultural funding to the smallholder farmers by the institutional sector in Nigeria majorly come from the Government, the international donor agencies and the commercial banks. With so much funds coming from the institutional sector, it will be expected that there should be a corresponding growth in the level of farming techniques, agricultural production, state of technology and an eventual hype in the contribution of agriculture to the gross domestic product of the country, but these expected impacts are yet to be seen in the smallholder farming industry. The state of agriculture remains at almost its status quo of over 50 years characterized by crude techniques of farming with mechanization still at its barest minimum. Most existing studies focused on the need to acquire funding for agricultural activities in Nigeria (Adesugba \& Mavrotas, 2016), other studies have examined the various funding programs and policies in Nigeria (Gbandi \& Amissah, 2014), but to the best of my knowledge, limited studies have been carried out to access the impact of institutional finance on smallholder farming activities in Nigeria.

\section{CONCLUSION}

The contribution of this literature review is to primarily present a review of agricultural finance as a topic and serve as a guide for both researchers and practitioners on the subject of agricultural finance in Nigeria. It is also aimed at highlighting the perspectives of researchers who have previously studied this subject, the identifiable benefits of agricultural finance, and the methodology used in conducting the research. Secondly, this paper aims to pinpoint opportunities for future research.

Overall, the literature review has revealed that the subject of agricultural finance has been addressed from the perspective of the finance provider as well as from the viewpoint of the beneficiary farmers. From the perspective of the beneficiary smallholder farmers, the literature review revealed that there are tangible benefits accruable to the smallholder farmers who benefits from the funds provided. These benefits include but not limited to the ability of the smallholder farmer to be able to acquire modern machinery, purchase improved varieties of farms inputs, and employ the 
necessary experienced hands. On the other hand, the literature review which focused on the viewpoint of the financial providers identifies the concerns of the financial providers to the ability of the smallholder farmers to be able to repay the funds advanced to them by banks and government agencies, and for those that benefited from aids, the concerns are that the beneficiary smallholder farmers are able to utilize the funds appropriately for their farming activities, while having the knowledge that they might not be required to repay the funds. In terms of the methodologies, the review shows that most studies focusing on the general scope of agricultural finance are conceptual, while those focusing on the provision of finance for agricultural purpose utilize analytical models. Further, the review reveals that there are several gaps in the reviewed literature which presents a direction for future research in the area of provision of finance for agricultural use in Nigeria.

First, there is the need to develop a broader theory regarding agricultural finance in Nigeria, as the funds are provided by different providers and different term of funding applies. Secondly, the results of the empirical methods used to study of the use of agricultural finance by smallholder farmers is weak as it only studies the relation between smallholder farmers and their use of the provided funding for agricultural development. However, it should be noted that the smallholder farmers do not operate in as a single entity, rather, they are affected by several other factors which constitutes a system within which the farmers operate, hence, the study need to consider the ripple effect of the funds provided to the farmers. Thirdly, many smallholder farmers are not literate and therefore have poor record keeping technique in place. Finally, there are only few smallholder farmers who are willing to voluntarily disclose facts and figures about their finances except when they are sure that there is a benefit attached to it.

This study however has a limitation. While concerted effort was made to ensure that this review is comprehensive and inclusive of the relevant papers, it is however possible that some related research works in this area may have been overlooked. However, the author believe that this literature review is an accurate representation of the body of research on agricultural finance in Nigeria published during the understudied time frame.

\section{REFERENCES}

[1] Adesina, A. (2013). Why Agriculture Is Nigeria's New Oil. Retrieved 14th May, 2018, from The Forbes https://www.forbes.com/sites/skollworldforum/2013/10/10/why-agricu lture-is- nigerias-new-oil/\#6b3d8afe6d4a

[2] Adesugba, M. A., \& Mavrotas, G. (2016). Delving deeper into the agricultural transformation and youth employment nexus: The Nigerian case (Vol. 31): Intl Food Policy Res Inst. Afolabi, J. A. (2010). Analysis of Loan Repayment Among Small Scale Farmers in Oyo State,

[3] Nigeria. Journal of social sciences, 22(2), 115-119.

[4] Akinola, F. (2013). The Challenges of Agricultural Finance in Nigeria: Constraints to Sustainable Agricultural and Economic Revival. International Journal of Business and Social Research, 3(5), 234-244.

[5] Ali, M. A., Poomthan, R., \& Warunsiri, P. S. (2016). Decomposition of agricultural productivity growth in Africa. African Journal of Economic $\begin{array}{llll}\text { and Management Studies, } & 7(4), & 497-509\end{array}$ doi:doi:10.1108/AJEMS-02-2015-0019

[6] Bezemer, D., \& Headey, D. (2008). Agriculture, Development, and Urban Bias. World Development, 36(8), 1342-1364. doi:https://doi.org/10.1016/j.worlddev.2007.07.001
[7] Birthal, P. S., Chand, R., Joshi, P. K., Saxena, R., Rajkhowa, P., Khan, M. T., ... Chaudhary, K. R. (2017). Formal versus informal: Efficiency, inclusiveness and financing of dairy value chains in Indian Punjab. Journal of Rural Studies, 54, 288-303. doi:10.1016/j.jrurstud.2017.06.009

[8] Budget Office. (2018). Overview of the 2013 - 2018 Budget Proposal Retrieved 28th April 2018, from Budget Office of the Federation Federal Republic of Nigeria http://www.budgetoffice.gov.ng/index.php/2014-budget

[9] Central Bank of Nigeria. (2017). Financial Stability Report - June $2017 . \quad$ Retrieved from https://www.cbn.gov.ng/Out/2018/FPRD/FSR\%20June\%202017\%20( Revised\%20-\%20SA\%20Comments).pdf

[10] Central Bank of Nigeria. (2018). Development Finance: Agricultural Credit. Retrieved 29th April, 2018, from Central Bank of Nigeria https://www.cbn.gov.ng/devfin/acgsf.asp

[11] Chukwuma Sr, C. (2014). Convergence of the Nigerian food and agricultural crisis on sustainable development. Journal of Agricultural Extension and Rural Development, 6(2), 61-68.

[12] Coker, A., \& Audu, M. (2015). Agricultural micro-credit repayment performance: Evidence from Minna Microfinance Bank, Nigeria. African Journal of Agricultural Research, 10(9), 877- 885.

[13] Daneji, M. (2011). Agricultural development intervention programmes in Nigeria (1960 to date): A review. Savannah Journal of Agriculture, $6(1), 1-7$.

[14] Dercon, S., \& Gollin, D. (2014). Agriculture in African Development: Theories and Strategies. Annual Review of Resource Economics, 6(1), 471-492. doi:10.1146/annurev-resource- 100913-012706

[15] Diao, X., \& McMillan, M. (2017). Toward an Understanding of Economic Growth in Africa: A Reinterpretation of the Lewis Model. World doi:https://doi.org/10.1016/j.worlddev.2016.12.008

Development.

[16] Eicher, C. (2003). Flashback: Fifty Years of Donor Aid to African Agriculture. Michigan State University.

[17] Ejiogu, A. O. (2018). Agricultural Finance and Opportunities for Investment and Expansion (Vol. Advances in Finance, Accounting and Economics AFAE): IGI Global. Ellinger, \& Penson, P. J. (2014). Agricultural Finance. In (pp. 92-104)

[18] Eluhaiwe, P. N. (2014). Agriculture and Finance in Nigeria: Experiences and Lessons. Paper presented at the Agriculture Stakeholders Session at the Nigeria Development Finance Forum, New York U.S.A. http://slideplayer.com/slide/5827462/

[19] Evbuomwan, G. O. (2016). Financing Agriculture for Sustainable Economic Development. Bullion publication of the central bank of nigeria, 40(3)

[20] Eze, C. C., Lemchi, J., Ugochukwu, A. I., Eze, V., Awulonu, C., \& Okon, A. (2010). Agricultural financing policies and rural development in Nigeria. Paper presented at the 84th Annual Conference, March 29-31, 2010, Edinburgh, Scotland.

[21] Fadeyi, O. A. (2013). An Assessment of Community Banks' Effects on Agricultural Development: The Case of Ogun State, Nigeria.

[22] Falola, A., Ayinde, O. E., \& Agboola, B. O. (2014). Willingness to take agricultural insurance by cocoa farmers in Nigeria.

[23] Fløgstad, C., \& Hagen, R. J. (2017). Aid Dispersion: Measurement in Principle and Practice. World Development, 97, 232-250. doi:https://doi.org/10.1016/j.worlddev.2017.04.022

[24] Gbandi, E., \& Amissah, G. (2014). Financing options for small and medium enterprises (SMEs) in Nigeria. European Scientific Journal, ESJ, 10(1).

[25] Harris M. Cooper, Erika A. Patall, \& James J. Lindsay. (2009). Research Synthesis and Meta- Analysis. In the SAGE Handbook of Applied Social Research Methods (2 ed.). Thousand Oaks, California: SAGE Publications, Inc. Retrieved from http://methods.sagepub.com/book/the-sage-handbook-of-applied-socia 1-research- methods-2e. doi:10.4135/9781483348858

[26] Hartarska, V., Nadolnyak, D., \& Shen, X. (2015). Agricultural Credit and Economic Growth in Rural Areas. Agricultural Finance Review. 75(3), 302-312. doi:doi:10.1108/AFR-04-2015- 0018

[27] IFAD. (2018). IFAD Operations: Nigeria. Retrieved 29th April, 2018 , from International Fund for Agricultural Development https://www.ifad.org/web/operations/country/id/nigeria

[28] IFC. (2011). Scaling Up Access to Finance for Agricultural SMEs Policy Review and Recommendations. Retrieved from

[29] Iwuchukwu, J., \& Igbokwe, E. (2012). Lessons from agricultural policies and programmes in Nigeria. JL Pol'y \& Globalization, 5, 11

[30] Jones, A. D.. \& Ejeta, G. (2016). A new global agenda for nutrition and health: the importance of agriculture and food systems. Bulletin of the World Health Organization, 94(3), 228

[31] Kersten, R., Harms, J., Liket, K., \& Maas, K. (2017). Small Firms, large 
Impact? A systematic review of the SME Finance Literature. World Development, 97, 330-348. doi:10.1016/j.worlddev.2017.04.012

[32] Lowder, S., Carisma, B., \& Skoet, J. (2012). Who Invests in Agriculture and How Much. Marris, P. (2018). Dilemmas of social reform: poverty and community action in the United

[33] States: Routledge.

[34] Martin, S. J., \& Clapp, J. (2015). Finance for Agriculture or Agriculture for Finance? Journal of Agrarian Change, 15(4), 549-559. doi:10.1111/joac. 12110

[35] Mattia, G. L., Riccardo, M., Alessandro, P., \& Angela, T. (2016). Supply chain finance: a literature review. International Journal of Physical Distribution \& Logistics Management, 46(4), 348-366. doi:doi:10.1108/IJPDLM-08-2014-0173

[36] Miller, C., \& Jones, L. (2010). Agricultural value chain finance: Tools and lessons: Food and Agriculture Organization of the United Nations and Practical Action Pub.

[37] Mogues, T., \& Dillon, A. D. A. (2018). Nigeria Agriculture Public Expenditure Review (NAGPER) and Planned Research on Agricultural Subsidies and the Health- Productivity Nexus. International Food Policy Research Institute.

[38] National Bureau of Statistics. (2007). Nigeria - National Agricultural Sample Census Pilot (Private Farmer) Livestock and Poultry-2007, Second round. Retrieved 30th April, 2018, from National Bureau of Statistics (NBS) - Federal Government of Nigeria(FGN) http://www.nigerianstat.gov.ng/nada/index.php/catalog/16

[39] National Bureau of Statistics. (2017). Nigerian Gross Domestic Product Report (Expenditure and Income Approach) (Q3-Q4 2016). Retrieved from Ndikumana, L., \& Pickbourn, L. (2017). The Impact of Foreign Aid Allocation on Access to Social Services in sub-Saharan Africa: The Case of Water and Sanitation. World Development, 90, 104-114. doi:https://doi.org/10.1016/j.worlddev.2016.09.001

[40] OECD. (2016). Agriculture in Sub-Saharan Africa: Prospects and challenges for the next decade. Organisation for Economic Co-operation and Development - FAO Agricultural Outlook, 59-95.

[41] OECD. (2018). Agriculture-Related Aid Data at A Glance - By Receipient. Retrieved 30th April, 2018, from Organisation for Economic Co-operation and Development http://www.oecd.org/dac/stats/agriculture-relatedaiddataataglance.htm

[42] Ofoegbu, D. I. (2015). A Review of The Federal Government 2015 Budget Proposal Retrieved $28^{\text {th }}$ April, 2018, from Centre for Social Justice, Abuja, Nigeria

[43] Okoro, F. N., \& Nwali, N. I. (2017). Agricultural Funding and Challenges of Deposit Money Banks in Nigeria. Arabian Journal of Business and Management Review, 7(5).

[44] Okotie, S. (2018). The Nigerian Economy Before the Discovery of Crude Oil. In P. E. Ndimele (Ed.), The Political Ecology of Oil and Gas Activities in the Nigerian Aquatic Ecosystem (pp. 71-81): Academic Press.

[45] Olajide, O., Akinlabi, B., \& Tijani, A. (2012). Agriculture resource and economic growth in Nigeria. European Scientific Journal, ESJ, 8(22).

[46] Olomola, A. S. (2010). Agricultural finance. In (pp. 51-62).

[47] Omorogiuwa, O., Zivkovic, J., \& Ademoh, F. (2014). The role of agriculture in the economic development of Nigeria. European Scientific Journal, ESJ, 10(4).

[48] Orebiyi, J., Eze, C., Henri-Ukoha, A., Akubude, F., \& Ibitoye, S. (2011). Demand for institutional credit from the NACRDB by small scale farmers in Imo state, Nigeria. International Journal of Agricultural Science, Research and Technology (IJASRT), 1(2), 83-87.

[49] Pardey, P. G., Chan-Kang, C., Dehmer, S. P., \& Beddow, J. M. (2016). Agricultural R\&D Is On The Move. Nature News, 537(7620), 301.

[50] Röttger, D. (2015). Agricultural finance for smallholder farmers: Rethinking traditional microfinance risk and cost management approaches (Vol. 11): Columbia University Press.

[51] Taiwo, J. N., \& Olurinola, I. O. (2016). Demand and utilization of Micro loan among Micro Entrepreneurs in Nigeria. International Journal of Economics, Commerce and Management United Kingdom. 4(6), 275-299.

[52] Tersoo, P. (2014). Agribusiness as a veritable tool for rural development in Nigeria. International Letters of Social and Humanistic Sciences, 3, 26-36.

[53] Trading Economics. (2018). Nigeria - Employment in Agriculture (\% of Total Employment). Retrieved 25th April, 2018, from Trading Economics

https://tradingeconomics.com/nigeria/employment-in-agriculture-perce nt-of-total- employment-wb-data.html

[54] United Nations. (2015). We Can End Poverty - Millenium Development Goals and Beyond 2015. Available from United Nations, from United Nations http://www.un.org/millenniumgoals/

[55] Valentina, H., Denis, N., \& Xuan, S. (2015). Agricultural credit and economic growth in rural areas. Agricultural Finance Review, 75(3), 302-312. doi:doi:10.1108/AFR-04-2015-0018

[56] World Bank. (2014). World Bank Staff Estimates Based on The United Nations Population Divisions World Urbanization Prospects: 2014 Revision.

[57] World Bank. (2016). Population Growth (Annual \%). Retrieved from https://data.worldbank.org/indicator/SP.POP.GROW?locations=ZG

[58] World Bank. (2018). Nigeria: Distribution of Gross Domestic Product GDP Across Economics Sectors from 2006 to 2016.

[59] World Bank. (2018). Population Estimates and Projections. Databank.

[60] Yahaya, K., \& Osemene, O. (2011). Effectiveness of microfinance banks in alleviating poverty in Kwara State Nigeria. Global Journal of Management and Business Research, 11(4).

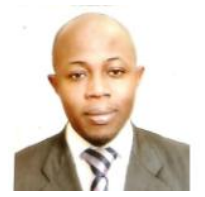

Oluwamayokun Anjorin Fadeyi holds a bachelor's degree in Agric Economics and Farm Management from the University of Agriculture, Abeokuta, Nigeria, and a master's degree in International Management from the University of Liverpool, United Kingdom. He is presently undertaking his postgraduate research study in Agribusiness at the University of Queensland, Australia.

His research interests are in the areas of agricultural financing, smallholder farming development, rural extension and development. He is presently an Associate Certified Economist (ACE) with the Institute of Certified economist of Nigeria (ICEN), a graduate member of the Nigeria Institute of Management (NIM) 